3. It is suggested that carotene is synthesized by the micro-organisms of the ileum and caecum. Such synthesis of carotene by intestinal micro-organisms has been demonstrated on an agar medium inoculated with caecal contents.

The interest and helpful advice of Dr C. R. Barnicoat, Head of the Biochemistry Department during the course of this investigation, is gratefully acknowledged. The work was carried out during the tenure of a University Research Fellowship and financed by University Research Grants.

\title{
REFERENCES
}

Barrick, E. R., Andrews, F. N. \& Bullard, J. F. (1948). Y. Anim. Sci. 7, 539.

Booth, V. H. (1945). F. Soc. chem. Ind., Lond., 64, 162.

Ellis, G. H., Matrone, G. \& Maynard, L. A. (1946). F. Anim. Sci. 5, 285.

Hume, E. M. \& Krebs, H. A. (1949). Spec. Rep. Ser. med. Res. Coun., Lond., no. 264.

MacDougall, D. \& DeLong, W. A. (1948a). Canad. F. Res. B, 26, 457.

MacDougall, D. \& DeLong, W. A. (1948b). Canad. F. Res. B, 26, 464 .

MacDougall, D. \& DeLong, W. A. (1948c). Canad. F. Res. B, 26, 468.

McGillivray, W. A. (1950). N.Z. Y. Sci. Tech., B. (In the Press.)

Moore, L. A. \& Ely, R. (1941). Industr. Engng Chem. (Anal. ed.), 13, 600.

Whitnah, C. H., Peterson, W. J., Atkeson, F. W. \& Cave, H. W. (1939). Y. agric. Res. 58, 343.

Zechmeister, L. \& Cholnoky, I.. (1943). Principles and Practice of Chromatography, and ed. London: Chapman and Hall.

\section{The Composition of Human Milk with Special Reference to the Relation between Phosphorus Partition and Phosphatase and to the Partition of Certain Vitamins}

\author{
By R. CHANDA AND E. C. OWEN \\ Hannah Dairy Research Institute, Kirkhill, Ayr \\ AND BERTINE CRAMOND \\ Midwifery Department, University of Aberdeen and the Aberdeen \\ Maternity Hospital
}

(Received 13 November 1950)

Two of the present authors are making a detailed study of the composition of the milk and colostrum of cows and goats, as affected by hormonal and nutritional influences. The results, which will be published shortly, showed that ester phosphorus was negatively correlated with phosphatase, the coefficient of correlation being -0.95 . In cows treated with thyroxine or thiouracil the same correlation obtained (Chanda \& Owen, 1949). Lipid phosphorus and phosphatase were similarly correlated. During the change from colostrum to milk the correlations were still found. There was likewise (Chanda, McNaught \& Owen, 1949) a negative correlation between phosphatase and phosphorylated vitamin $B_{1}$ in milk, as previously reported by Houston, Kon \& Thompson (1940). The present work was undertaken to see whether the changes in human milk at the beginning of lactation were at all comparable with those in cow's 
milk immediately after parturition or after hormone treatment. At the same time the partitions of carotenoids and of vitamin A were studied and some samples were tested for nicotinic acid.

During the recent war Kon \& Mawson (1950) made a detailed study, reported to the Medical Research Council, of the changes in chemical composition of human milk throughout lactation. In their report, to which reference is again made in the discussion of the present results, nutritional influences on the composition of human milk were studied. The importance at present attached to natural variations in the composition of human milk is brought out also by Clements (1949).

\section{EXPERIMENTAL}

Collection of samples. One of us (B.C.) was responsible for collecting the milk and despatching it to the Hannah Institute for analysis. No milk was collected in the summer months to obviate the risk of possible changes in transit. Analyses were completed within $48 \mathrm{hr}$. of arrival of the samples at the laboratory. The total number of samples collected was fifty-two, but analyses for all the constituents studied could not be made on all of them. The number for which it was possible to make analyses is stated at the head of the relevant table.

Methods of analysis. Fats, solids-not-fat and protein were determined by the methods normally used for cow's milk at the Institute.

Phosphorus was partitioned by a slight modification of the method of Graham \& Kay (1934). Trichloroacetic acid was cooled before use to avoid hydrolysis of phosphoric esters. The digestion of phosphorus compounds to phosphoric acid was carried out in micro-Kjeldahl flasks with concentrated $\mathrm{H}_{2} \mathrm{SO}_{4}$ and $30 \% \mathrm{H}_{2} \mathrm{O}_{2}$ (Horecker, $\mathrm{Ma} \&$ Haas, 1940). Phosphoric acid was estimated by the method of Fiske \& Subbarow (1925), with the aid of a Spekker absorptiometer.

Phosphatase could not be estimated by the short test of Kay \& Graham (1935), and the long test ( $24 \pm 2 \mathrm{hr}$. incubation), as modified by Neave (1939), was, therefore, used. The results are expressed arbitrarily as units which represent the number of $\mathrm{mg}$. of phenol liberated from the British Drug Houses buffer-substrate tablets by the amount of enzyme in $100 \mathrm{ml}$. milk.

Vitamin $B_{1}$ was estimated in skimmed milk before and after treatment with takadiastase (Houston, et al. 1940). Takadiastase contains takaphosphatase (Kinnersley \& Peters, 1938). Free vitamin $B_{1}$ was estimated by Jansen's method.

Nicotinic acid was estimated microbiologically by the method of Barton-Wright (1944) with Lactobacillus arabinosus 17/5. Acid production was determined by titration. Since the medium was brownish after incubation, a glass electrode and a Cambridge potentiometer were used to ensure titration to a constant $\mathrm{pH}$.

In estimating carotenoids and vitamin $\mathrm{A}$, it was found that besides $\beta$-carotene and xanthophyll, human milk fat contained appreciable amounts of $\alpha$-carotene and lycopene. These substances were therefore separated chromatographically. The procedure for separating carotenoids, vitamin $A$ ester and vitamin $A$ alcohol was essentially that described by Ganguly, Kon \& Thompson (1947). Lycopene, $\alpha$-carotene and $\beta$-carotene were estimated as described below. 
All the solvents used were purified. Diethyl ether was freed from peroxide by treatment with stannous chloride followed by distillation. Light petroleum and $n$-hexane were freed from aromatic hydrocarbons by treatment with $\mathrm{H}_{2} \mathrm{SO}_{4}$ (density $\mathrm{I} \cdot 84 \mathrm{~g} . / \mathrm{ml}$.), followed by distillation. Acetone was redistilled. Ethanol was freed from aldehydes by treatment with $\mathrm{KOH}$ and $\mathrm{AgNO}_{3}$ followed by distillation just before use. The fat was extracted from the milk by a method based on that of Olson, Hegsted \& Peterson (1939). To $50 \mathrm{ml}$. milk taken in a $250 \mathrm{ml}$. separating funnel, $7.5 \mathrm{ml} .35 \%$ ammonia were added. After vigorous shaking the contents were allowed to stand for from 3 to $5 \mathrm{~min}$., after which $30 \mathrm{ml}$. ethanol, $35 \mathrm{ml}$. freshly distilled diethyl ether and $15 \mathrm{ml}$. light petroleum (b.p. $40^{\circ}-60^{\circ}$ ) were added successively, the mixture being shaken after each addition. The separating funnel was then allowed to stand till the layers were cleanly separated. The lower layer was run off into a flask and the top layer collected in another flask. The lower layer was transferred back into the separating funnel and again extracted with $25 \mathrm{ml}$. diethyl ether and ro $\mathrm{ml}$. light petroleum. The two extracts were combined and allowed to stand in the separating funnel for $30 \mathrm{~min}$. Any aqueous layer that separated was drawn off. After having been washed twice with $5 \circ \mathrm{ml}$. portions of warm tap water with gentle shaking to avoid any formation of emulsion, the ether layer was dried over sodium sulphate and poured into a widemouthed flask. The sodium sulphate was washed twice with small volumes of ether which were added to the flask. The ether was removed by evaporation under reduced pressure on a water-bath at $70^{\circ}$. The fat so obtained was taken up in $5 \mathrm{ml} . n$-hexane and chromatographed in a $4 \times 1 \mathrm{~cm}$. column of alumina (Savory and Moore Ltd., London) previously moistened with $n$-hexane. $\alpha$ - and $\beta$-carotene, lycopene and vitamin $A$ ester for the most part ran through with the fat. Addition of $20 \mathrm{ml}$. of $3 \%$ acetone in $n$-hexane served to complete the elution but kept the vitamin $A$ alcohol still on the column. The eluates of the same sample were combined (fraction I). Vitamin $A$ alcohol was then eluted with $20 \mathrm{ml}$. of $8 \%$ ethanol in $n$-hexane, and the eluate was evaporated to dryness at $70^{\circ}$ under reduced pressure. As soon as the solvent had all evaporated, the residue was taken up in $5 \mathrm{ml}$. $n$-hexane and its spectral absorption in ultraviolet light at $328 \mathrm{~m} \mu$. was determined with use of the correction of Morton \& Stubbs (I946).

Fraction I was evaporated under reduced pressure, and the fat saponified with I $g$. $\mathrm{KOH}$ and $20 \mathrm{ml}$. alcohol by boiling for $5 \mathrm{~min}$. The contents were diluted with three volumes of ice-cold water and the mixture was allowed to cool in the dark. The solution was then transferred to a separating funnel and extracted firstly with $5^{\circ}$, then with $3^{\circ}$ and finally with $20 \mathrm{ml}$. peroxide-free diethyl ether. The extracts were combined and washed with three $50 \mathrm{ml}$. lots of distilled water, shaking being gentle with the first and vigorous with the second and third lots. It was found necessary sometimes to use a little $\mathrm{N}-\mathrm{HCl}$ in the second washing to remove the alkali completely. The final washing was tested to make sure that the extract was free from acid or alkali. The extract was dried over sodium sulphate, evaporated in a wide-mouthed flask under reduced pressure and then taken up in $5 \mathrm{ml}$. $n$-hexane before being chromatographed again on a $4 \times 1 \mathrm{~cm}$. column of alumina. $\alpha$ - and $\beta$-carotene were eluted with $3 \%$ acetone in $n$-hexane. The eluate was made up to a suitable volume after evaporation at reduced pressure and the concentration of the carotenes was read in the spectrophotometer at $45 \mathrm{I} \mathrm{m} \mu$. 
with a tungsten lamp. Vitamin $A$ ester of the original fat, now converted to vitamin $A$ alcohol by the saponification, remained adsorbed on the column with the lycopene. The lycopene and vitamin $\mathrm{A}$ alcohol were eluted together by $10 \%$ acetone in $n$-hexane. Lycopene was estimated in the spectrophotometer by its absorption at $505 \mathrm{~m} \mu$. The value for $E_{1 \mathrm{~cm}}^{1 \%}$. in $n$-hexane was taken as 2000 (Morton, 1942).

It was not possible to estimate vitamin $A$ in the same solution because the ultraviolet absorption of lycopene overlapped that of vitamin A. Fig. I shows that the

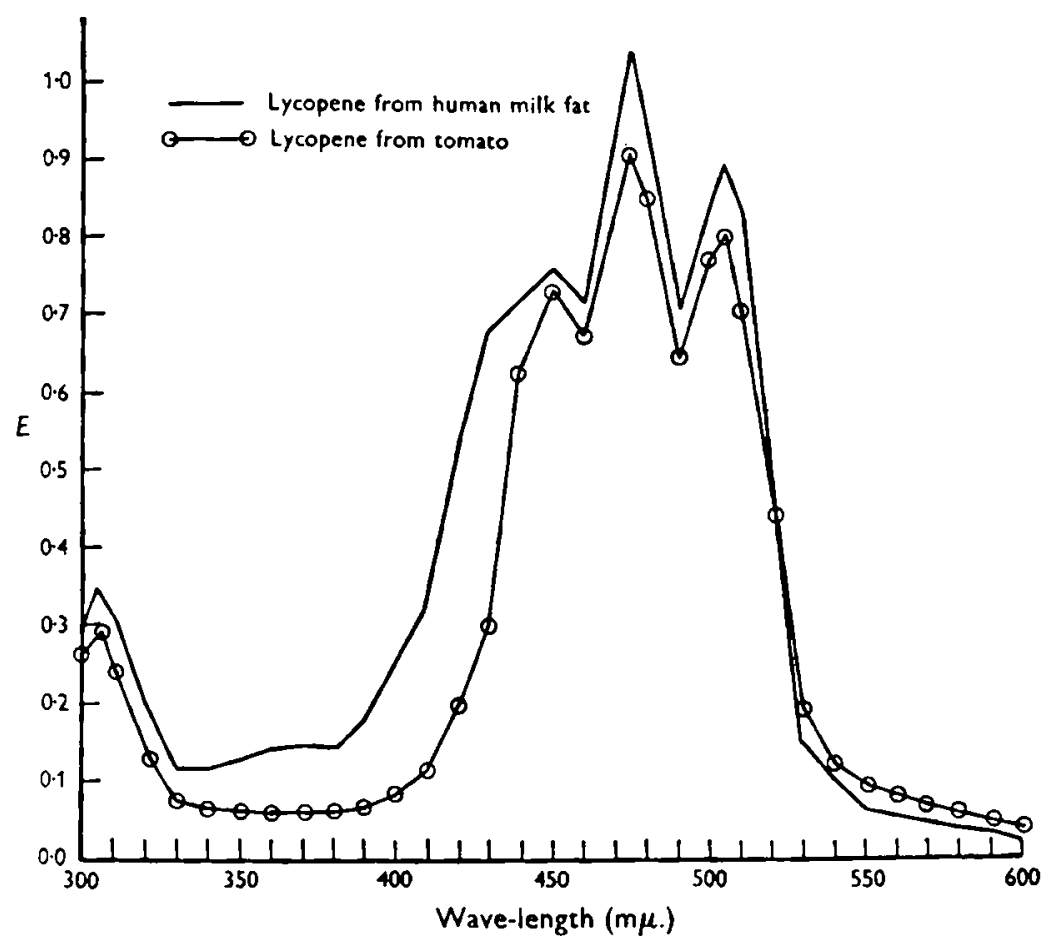

Fig. I. Absorption spectrum of lycopene from tomato dissolved in $n$-hexane and of the red pigment from human milk. Both pigments were purified by adsorption chromatography on alumina.

absorption curve of lycopene has a distinct bend near $328 \mathrm{~m} \mu$., so that the conditions defined by Morton \& Stubbs (1946) for correction for irrelevant absorption did not obtain. Lycopene and vitamin $A$ were, however, separated by the following methods. When fat containing vitamin $A$ and carotenoids is chromatographed in $n$-hexane, lycopene can be held on the column of alumina, while the elution of carotene and vitamin A ester is completed with $3 \%$ acetone in $n$-hexane, provided a sufficiently long column is used and the concentration of fat on the column is not too large. By adjusting the length of the column and decreasing the amount of material taken, the concentration of fat on the column is reduced, and vitamin A ester, free from lycopene, can be eluted. Accordingly, for the estimation of vitamin A ester a separate sample was extracted from the milk as already described, and chromatographed in two portions each in a $6 \times 1 \mathrm{~cm}$. column of alumina. By thus reducing the concentration of fat, the more slowly moving band of lycopene was retained, while $\alpha$ - and $\beta$-carotene and 
vitamin A ester were eluted with the fat. Further elution of the column with $3 \%$ acetone in $n$-hexane did not induce any appreciable movement of the lycopene band. The two eluates of the same sample, consisting of carotene and vitamin A ester, were combined and evaporated under reduced pressure. The fat was saponified. Carotene and vitamin $A$ were extracted with ether as before and the final ether extract evaporated to dryness. The residue was taken up in $3 \mathrm{ml} . n$-hexane and chromatographed again. $\alpha$ - and $\beta$-carotene were eluted with $3 \%$ acetone in $n$-hexane, and vitamin $A$ ester, now converted to vitamin $\mathrm{A}$ alcohol, was eluted separately with $8 \%$ ethanol in $n$-hexane.

After evaporation under reduced pressure the extracts were dissolved in a suitable volume of $n$-hexane and, with the spectrophotometer, the concentration was read for vitamin $A$ at $328 \mathrm{~m} \mu$. and for carotene at $45 \mathrm{I} \mathrm{m} \mu$. Further partition by separation of $\alpha$ - from $\beta$-carotene was accomplished by adsorption on a column of magnesia followed by elution with a I \% solution of acetone in $n$-hexane. It was assumed that $E_{1}^{1 \%} \mathrm{~cm} .45 \mathrm{I} \mathrm{m} \mu$. in $n$-hexane for the mixed carotenoids was 2400 . Actually, however, the constant is 2500 for $\beta$-carotene and 2200 for $\alpha$-carotene. $E_{1 \mathrm{om}}^{1 \%}$. for a sample of $\beta$-carotene supplied by British Drug Houses Ltd. was found to be $24 \mathrm{I} 5$ in the Unicam spectrophotometer used throughout the present experiments.

All the readings for vitamin A were corrected for irrelevant absorption by the threepoint method of Morton \& Stubbs ( 1946 ), and expressed as international units by use of the conversion factor of 1900 , attaching to the international unit and standard substance set up for vitamin A by the World Health Organization Expert Committee on Biological Standardization (1949).

\section{RESULTS}

General composition of milk. Table I shows the average composition of the fifty-two samples of milk. Each figure represents the average composition of all the milk samples obtained on the same day. The concentration of protein $(0.63 \%)$ was very small on the 2nd day post partum but became much bigger (2.01 \%) the next day and remained relatively constant thereafter. Changes of fat content were different from those of protein. The initial secretion tended to be richer in fat. The increase observed by the 28th day was probably attributable to diminution of yield, an interpretation in agreement

Table I. The mean content of protein, fat and solids other than fat in fifty-two samples of human milk collected from 2 to 28 days after parturition

\begin{tabular}{|c|c|c|c|c|}
\hline $\begin{array}{c}\text { Days } \\
\text { post } \\
\text { partum }\end{array}$ & $\begin{array}{l}\text { No. of } \\
\text { samples }\end{array}$ & $\begin{array}{l}\text { Protein* } \\
\text { (g. } / 100 \mathrm{ml} \text { ) }\end{array}$ & $\begin{array}{c}\text { Fat" } \\
\text { (g. } / 100 \mathrm{ml} .)\end{array}$ & $\begin{array}{l}\text { Solids not fat* } \\
\text { (g./100 ml.) }\end{array}$ \\
\hline 2 & 5 & $0.63 \pm 0.06$ & $3.4 \pm 0.15$ & $11.24 \pm 0.73$ \\
\hline 3 & II & $2.01 \pm 0.06$ & $2 \cdot 7 \pm 0.28$ & $9.77 \pm 0.01$ \\
\hline 4 & I0 & $1 \cdot 83 \pm 0.05$ & $3.0 \pm 0.30$ & $9.33 \pm 0.16$ \\
\hline 6 & 12 & $1.74 \pm 0.06$ & $2.5 \pm 0.10$ & $9.79 \pm 0.23$ \\
\hline 8 & 9 & $1.61 \pm 0.05$ & $2.9 \pm 0.20$ & $9.19 \pm 0.22$ \\
\hline 10 & I & $1 \cdot 82$ & $3 \cdot 1$ & $9 \cdot 39$ \\
\hline 12 & I & $x \cdot 67$ & $2 \cdot 8$ & $9 \cdot 5^{2}$ \\
\hline 28 & 3 & $1 \cdot 74 \pm 0.04$ & $3.9 \pm 0.27$ & $9 \cdot 26 \pm 0.08$ \\
\hline
\end{tabular}


with that of Kon \& Mawson (1950). The percentage of non-fatty solids was at a maxi-

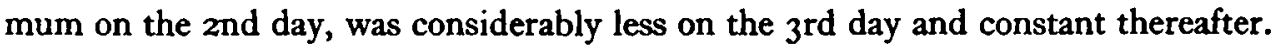

Partition of phosphorus fractions. The total content of phosphorus and the partition of the various phosphorus fractions is shown in Table 2 for thirty-four of the samples of colostrum and transitional milk collected from the and to the 12th day post partum. The coefficient of correlation of ester phosphorus with phosphatase is shown in Table 3 together with other coefficients of correlation to which reference will be made later.

Table 2. The mean content of phosphatase and the partition of the fractions of phosphorus in thirty-four samples of human milk collected from 2 to 12 days after parturition

\begin{tabular}{|c|c|c|c|c|c|}
\hline $\begin{array}{c}\text { Days } \\
\text { post } \\
\text { partum }\end{array}$ & $\begin{array}{l}\text { No. of } \\
\text { samples }\end{array}$ & $\begin{array}{c}\text { Total } \\
\text { phosphorus* } \\
\text { (mg./200 ml.) }\end{array}$ & $\begin{array}{c}\text { Ingrganic } \\
\text { phosphorus }{ }^{*} \\
\text { (mg./roo ml.) }\end{array}$ & $\begin{array}{c}\text { Ester } \\
\text { phosphorus*t } \\
\text { (mg./100 ml.) }\end{array}$ & $\begin{array}{c}\text { Phosphatase } \\
\text { (arbitrary } \\
\text { units } f \text { ) }\end{array}$ \\
\hline 2 & 4 & $13.3 \pm 1.03$ & $6.4 \pm 0.26(48.1)$ & $2 \cdot 8 \pm 0.52(2 I \cdot I)$ & $52 \cdot 5 \pm 3 \cdot 7$ \\
\hline 4 & 10 & $15.9 \pm 1.37$ & $4.5 \pm 0.45(28.3)$ & $5.3 \pm 0.54(33.3)$ & $29 \cdot 0 \pm 9 \cdot 8$ \\
\hline $\begin{array}{l}6 \\
8\end{array}$ & $\begin{array}{r}10 \\
8\end{array}$ & $\begin{array}{l}21 \cdot 7 \pm 2 \cdot 14 \\
18 \cdot 6 \pm 1 \cdot 60\end{array}$ & $\begin{array}{l}7.9 \pm 0.59(36.4) \\
6.5 \pm 0.62(34.9)\end{array}$ & $\begin{array}{l}5.6 \pm 0.90(25.8) \\
5.4 \pm 0.60(29.0)\end{array}$ & $\begin{array}{l}35 \cdot 7 \pm 4 \cdot 2 \\
35 \cdot 9 \pm 3 \cdot 9\end{array}$ \\
\hline 10 & $\mathbf{I}$ & $15 \cdot 7$ & $(33 \cdot 8)$ & $(38 \cdot 2)$ & $32 \cdot 2$ \\
\hline 12 & I & $20 \cdot 4$ & $(39 \cdot 2)$ & $(33 \cdot 3)$ & $29 \cdot 5$ \\
\hline
\end{tabular}

- Value with its standard error.

+ Figures in parentheses give this phosphorus expressed as a percentage of the total.

I Figures represent the number of $\mathrm{mg}$. phenol liberated per roo ml. milk (Kay \& Graham, 1935).

Table 3. Correlation between phosphatase and various other constituents of human milk

\section{Constituent}

Ester phosphorus

Ester phosphorus (as percentage of total phosphorus)

Inorganic phosphorus (as percentage of total phosphorus)

Lipid phosphorus

Lipid phosphorus (as percentage of total

phosphorus)

Free vitamin $B_{1}$

Free vitamin $B_{1}$ (as percentage of total vitamin $B_{1}$ )

Phosphorylated vitamin $B_{1}$ (as percentage of total vitamin $B_{1}$ )

\begin{tabular}{|c|c|c|}
\hline $\begin{array}{c}\text { Correlation } \\
\text { coefficient }\end{array}$ & $\begin{array}{l}\text { No. of paired } \\
\text { observations }\end{array}$ & Probability \\
\hline-0.8791 & 29 & $<0.001$ \\
\hline-0.8542 & 29 & $<0.001$ \\
\hline+0.8078 & 29 & $<0.001$ \\
\hline-0.5526 & 16 & $<0.05>0.02$ \\
\hline-0.5171 & 16 & $<0.05>0.02$ \\
\hline+0.7306 & 24 & $<0.001$ \\
\hline+0.9056 & 24 & $<0.001$ \\
\hline-0.9053 & 24 & $<0.001$ \\
\hline
\end{tabular}

Table 2, in which average figures are presented, and Table 3 show that the amount of ester phosphorus tended to be greater when that of phosphatase was smaller and vice versa. This correlation had been noted before in the lactating cow (Chanda \& Owen, 1949) and was one of the reasons for undertaking the present researches. The relationship between phosphatase and ester phosphorus is shown in Fig. 2, in which the curve was fitted by the method of least squares. The negative correlation between ester phosphorus and phosphatase is closer than would be thought from an inspection of the standard errors shown in Table 2 because, by averaging the samples for the same day the fact has been hidden that the correlation holds also within days.

The amount of lipid phosphorus (Tables 3 and 4 ) also was negatively correlated with 
that of phosphatase, but the amount of inorganic phosphate (Tables 2 and 3 ; Fig. 3) was positively correlated with the amount of phosphatase.

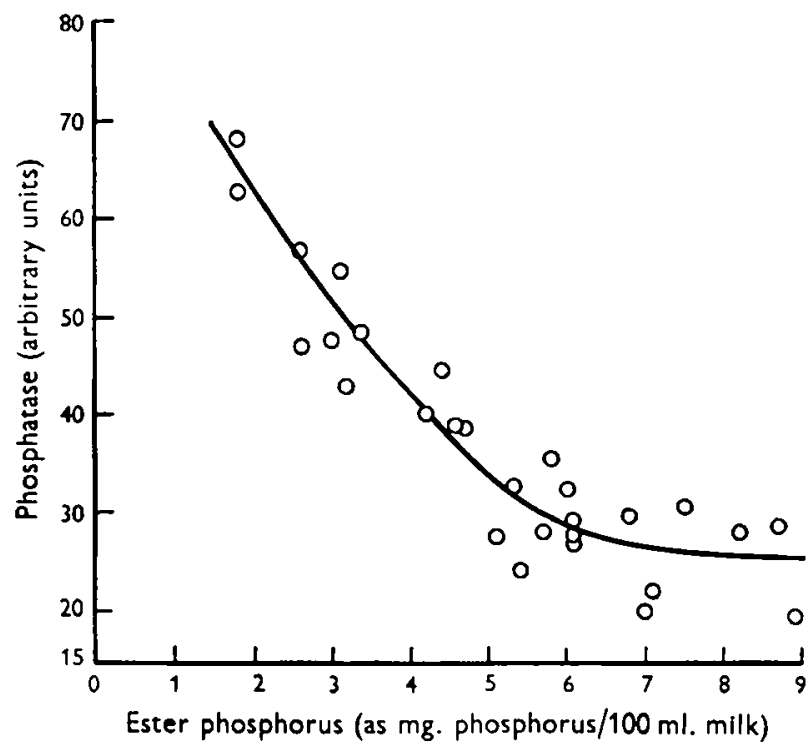

Fig. 2. Correlation between ester phosphorus and phosphatase in human milk.

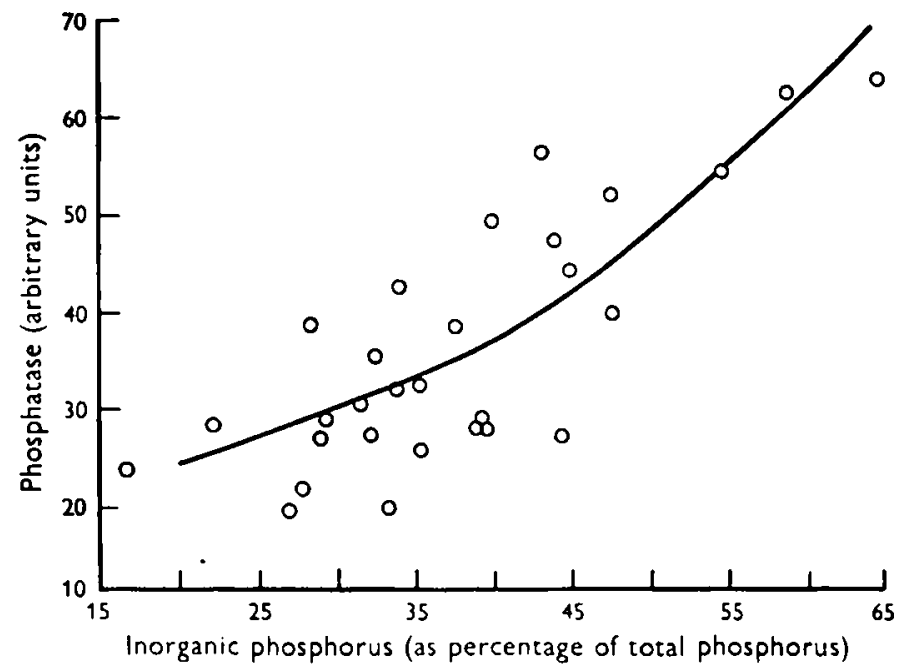

Fig. 3. Correlation between inorganic phosphorus (expressed as a percentage of the total phosphorus) and phosphatase in human milk.

Vitamin $B_{1}$ partition. The total amount of vitamin $\mathrm{B}_{1}$ was determined in twenty-four samples; it was small at first and increased to three times its initial value after about 8 or Io days (Table 5). Thereafter the rate of increase was slower. The ratio of phosphorylated to free vitamin $B_{1}$ increased during the ist week post partum and declined thereafter. There was a large negative correlation between the amount of phosphatase 
Table 4. The amount of phosphatase and of lipid phosphorus in sixteen individual samples of human milk collected from 2 to 12 days after parturition

Lipid phosphorus

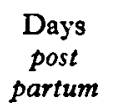

2

4

6

8

10

12

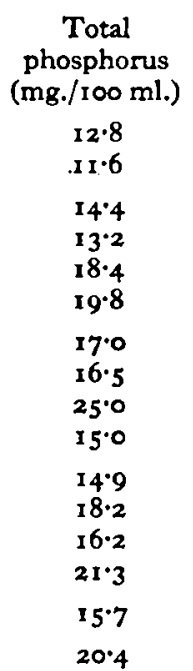

\begin{tabular}{cc}
\hline & $\begin{array}{c}\text { As percentage } \\
\text { of total } \\
\text { phosphorus }\end{array}$ \\
2.5 & 19.5 \\
1.5 & $12 \cdot 9$ \\
2.8 & 19.4 \\
$2 \cdot 2$ & 16.7 \\
$4 \cdot 1$ & 22.3 \\
4.9 & 24.7 \\
3.5 & 20.6 \\
3.2 & 19.4 \\
5.4 & 21.6 \\
3.1 & 20.7 \\
2.6 & 17.4 \\
3.6 & 19.8 \\
3.8 & 23.5 \\
4.0 & 18.7 \\
2.3 & 14.6 \\
3.2 & 15.7
\end{tabular}

Phosphatase
(arbitrary
units*)

$45 \cdot 6$

$62 \cdot 7$

25.9

$28 \cdot 6$

$27 \cdot 4$

$22 \cdot 0$

$32 \cdot 4$

$56 \cdot 4$

$28 \cdot 2$

40.0

44.4

$35 \cdot 4$

27.0

$38 \cdot 6$

$32 \cdot 2$

$29 \cdot 5$

- Figures represent the number of $\mathrm{mg}$. phenol liberated per $100 \mathrm{ml}$. milk (Kay \& Graham, 1935).

Table 5. The content of total and free vitamin $B_{1}$ in relation to the phosphatase content in twenty-four individual samples of human milk collected from 2 to 28 days after parturition

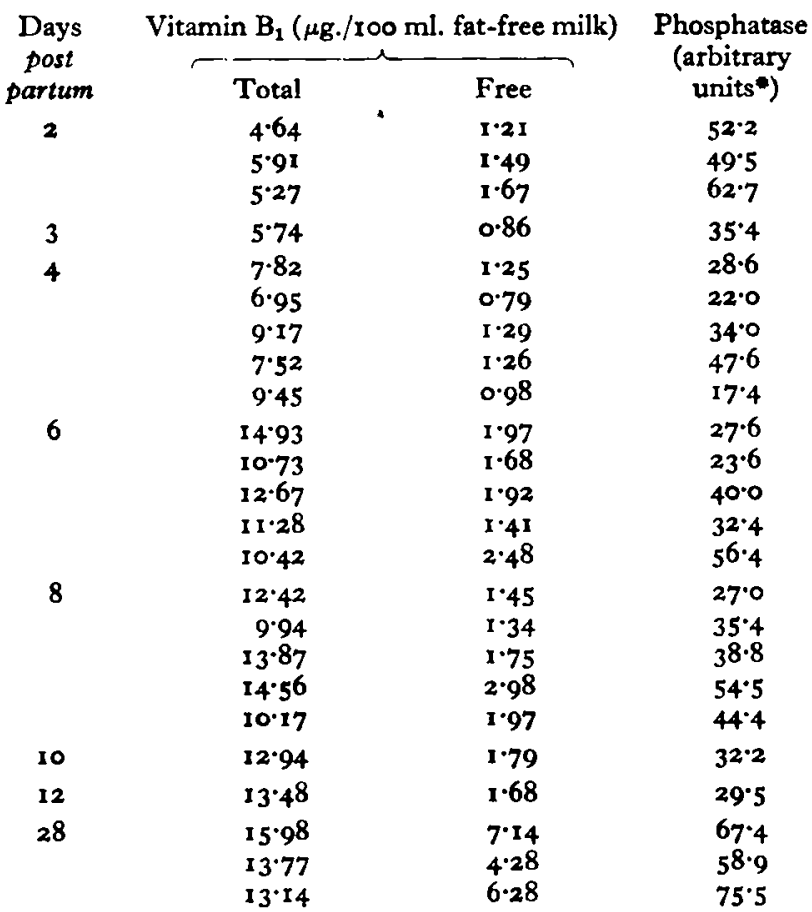

- Figures represent the number of $\mathrm{mg}$. phenol liberated per $100 \mathrm{ml}$. milk (Kay \& Graham, 1935). 
and of phosphorylated vitamin $B_{1}$ expressed as a percentage of the total amount of vitamin $B_{1}$ (Table 3); Fig. 4 shows the relationship graphically. Between the amount of phosphatase and of free vitamin $B_{1}$, expressed as a percentage of the total vitamin $B_{1}$, there was an equally large positive correlation.

Nicotinic acid. Nicotinic acid was estimated only in twelve samples, by Dr M. L. McNaught and Dr C. Higginbottom. The results are shown in Table 6, and demonstrate that the nicotinic acid content continued to increase up to the $4^{\text {th }}$ week of lactation, after which no further tests were made.

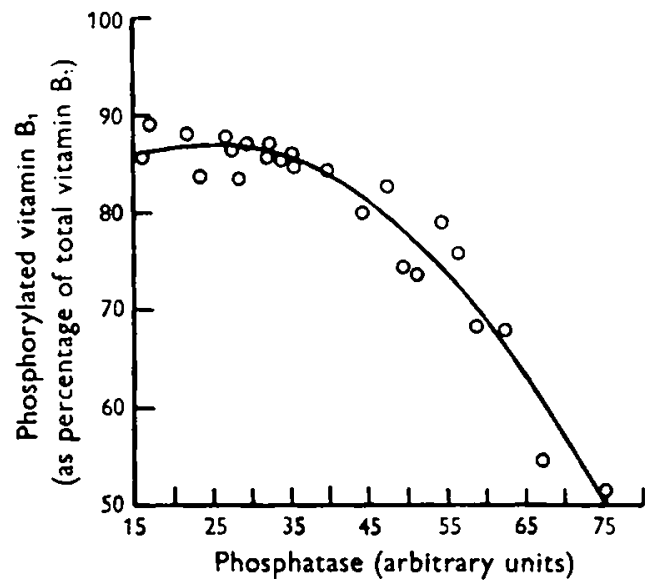

Fig. 4. Correlation between phosphorylated vitamin $B_{1}$ (expressed as a percentage of the total vitamin $\left.B_{1}\right)$ and phosphatase in human milk.

Table 6. The content of nicotinic acid in twelve individual samples of human milk, collected from 2 to 28 days after parturition

$\begin{array}{cccc}\begin{array}{c}\text { Days } \\ \text { post partum }\end{array} & \begin{array}{c}\text { Nicotinic acid } \\ (\mu \mathrm{g} . / \text { roo ml. })\end{array} & \begin{array}{c}\text { Days } \\ \text { post partum }\end{array} & \begin{array}{c}\text { Nicotinic acid } \\ (\mu \mathrm{g} . / \mathrm{r} 00 \mathrm{ml} \text {. })\end{array} \\ 3 & 42 & 7 & 58 \\ 3 & 56 & 8 & 101 \\ 3 & 39 & 8 & 6 \mathrm{I} \\ 4 & 86 & 28 & 103 \\ 4 & 8 \mathrm{I} & 28 & 180 \\ 7 & 97 & 28 & 226\end{array}$

Carotenoids and vitamin $A$. Carotenoids and vitamin $\mathrm{A}$ were estimated in twenty-six samples of milk; the results are recorded in Tables 7 and 8 . Chromatography showed that the fat from human milk contained xanthophylls, $\alpha$ - and $\beta$-carotenes and lycopene, of which the last three were measured spectrophotometrically. The presence of lycopene in human milk was reported by Thompson, Kon \& Mawson (1942). That the red carotenoid was lycopene in this instance also was demonstrated by comparing its properties with those of lycopene prepared from tomato. The pigments from the two sources showed only a single band when mixed and chromatographed. Their absorption spectra, in $n$-hexane solution, between 300 and $600 \mathrm{~m} \mu$. were compared and are shown graphically in Fig. I. The two curves are of the same shape and both have maxima at 
505,475 and $44^{8} \mathrm{~m} \mu$, in accordance with the findings of Morton (1942), that the absorption maxima for lycopene in light petroleum are at 506, 474 and $444 \mathrm{~m} \mu$.

Eight samples of milk were examined for $\alpha$ - and $\beta$-carotene separately, and both were identified by their spectral absorption and their chromatographic properties. Pure $\alpha$-carotene and the mixtures of $\alpha$ - and $\beta$-carotenes obtained from carrots and from

Table 7. Distribution of carotenoids and of the alcohol and ester fractions of vitamin $A$ in twenty-six individual samples of human milk, collected from 3 to 28 days after parturition

\begin{tabular}{|c|c|c|c|c|c|c|c|c|}
\hline \multirow[b]{2}{*}{$\begin{array}{c}\text { Days } \\
\text { post } \\
\text { partum }\end{array}$} & \multicolumn{3}{|c|}{ Carotenoids } & \multicolumn{3}{|c|}{ Vitamin A } & \multirow[b]{2}{*}{$\begin{array}{l}\text { Fat } \\
(\%)\end{array}$} & \multirow[b]{2}{*}{$\begin{array}{c}\text { Yield } \\
\text { of milk } \\
\text { (ml. daily) }\end{array}$} \\
\hline & $\begin{array}{c}\text { Total } \\
\text { ( } \mu \mathrm{g} . / 100 \mathrm{ml} .)\end{array}$ & $\begin{array}{c}\alpha \text { - and } \\
\beta \text {-carotene } \\
(\% \text { of total })\end{array}$ & $\begin{array}{l}\text { Lycopene } \\
\text { (\% of total) }\end{array}$ & $\begin{array}{c}\text { Ester } \\
\text { (i.u./roo ml.) }\end{array}$ & $\begin{array}{c}\text { Alcohol } \\
\text { (i.u./roo ml.) }\end{array}$ & $\begin{array}{c}\text { Total } \\
\text { (i.u./g. fat) }\end{array}$ & & \\
\hline 3 & $\begin{array}{l}120 \cdot 5 \\
145.3\end{array}$ & $\begin{array}{l}24.4 \\
25 \cdot 9\end{array}$ & $\begin{array}{l}50 \cdot 1 \\
49 \cdot 9\end{array}$ & $\begin{array}{l}254 \cdot 6 \\
600 \cdot 4\end{array}$ & $\begin{array}{l}27 \cdot 4 \\
49 \cdot 2\end{array}$ & $\begin{array}{l}156.7 \\
162.4\end{array}$ & $\begin{array}{l}1.8 \\
4.0\end{array}$ & $\begin{array}{l}130 \\
215\end{array}$ \\
\hline & $\begin{array}{l}137 \cdot 2 \\
118 \cdot 1 \\
109 \cdot 7\end{array}$ & $\begin{array}{l}28 \cdot 9 \\
28 \cdot 7 \\
38 \cdot 7\end{array}$ & $\begin{array}{l}48 \cdot 3 \\
46 \cdot 0 \\
31 \cdot 2\end{array}$ & $\begin{array}{l}359 \cdot 1 \\
318 \cdot 4 \\
522 \cdot 1\end{array}$ & $\begin{array}{l}45 \cdot 1 \\
32 \cdot 0 \\
57 \cdot 8\end{array}$ & $\begin{array}{l}202 \cdot 1 \\
206 \cdot 1 \\
148 \cdot 7\end{array}$ & $\begin{array}{l}4 \cdot 0 \\
1 \cdot 7 \\
3 \cdot 9\end{array}$ & $\begin{array}{l}117 \\
263 \\
363\end{array}$ \\
\hline & 114.5 & $27 \cdot 3$ & 40.5 & $\begin{array}{l}5221 \\
419 \cdot 3\end{array}$ & $29 \cdot 4$ & $\begin{array}{l}1407 \\
1870\end{array}$ & $\begin{array}{l}3.9 \\
2 \cdot 4\end{array}$ & $\begin{array}{l}303 \\
295\end{array}$ \\
\hline & $\begin{array}{r}99.4 \\
112.3 \\
125.6 \\
87.4\end{array}$ & $\begin{array}{l}22 \cdot 3 \\
24 \cdot 7 \\
24 \cdot 8 \\
27 \cdot 9\end{array}$ & $\begin{array}{l}52 \cdot 4 \\
43 \cdot 8 \\
40 \cdot 0 \\
44^{\cdot 1}\end{array}$ & $\begin{array}{l}304 \cdot 2 \\
450 \cdot 3 \\
547 \cdot 2 \\
388 \cdot 1\end{array}$ & $\begin{array}{l}19 \cdot 9 \\
26 \cdot 6 \\
39 \cdot 3 \\
21 \cdot 9\end{array}$ & $\begin{array}{l}190.6 \\
153.8 \\
162.9 \\
186.4\end{array}$ & $\begin{array}{l}1 \cdot 7 \\
3 \cdot 1 \\
3 \cdot 6 \\
2 \cdot 2\end{array}$ & $\begin{array}{l}150 \\
135 \\
205 \\
668\end{array}$ \\
\hline 4 & $\begin{array}{r}76 \cdot 4 \\
112 \cdot 3 \\
107 \cdot 6\end{array}$ & $\begin{array}{l}28.4 \\
25 \cdot 9 \\
23.8\end{array}$ & $\begin{array}{l}40 \cdot 7 \\
44 \cdot 3 \\
48 \cdot 9\end{array}$ & $\begin{array}{l}311 \cdot 7 \\
450 \cdot 0 \\
237 \cdot 0\end{array}$ & $\begin{array}{l}19 \cdot 3 \\
37 \cdot 2 \\
20 \cdot 7\end{array}$ & $\begin{array}{r}332 \cdot 4 \\
101 \cdot 5 \\
88 \cdot 9\end{array}$ & $\begin{array}{l}2 \cdot 5 \\
4 \cdot 8 \\
2 \cdot 9\end{array}$ & $\begin{array}{l}515 \\
187 \\
965\end{array}$ \\
\hline 5 & $\begin{array}{r}96.7 \\
87.5 \\
115.4\end{array}$ & $\begin{array}{l}28 \cdot 3 \\
22 \cdot 3 \\
28 \cdot 2\end{array}$ & $\begin{array}{l}45 \cdot 9 \\
47 \cdot 3 \\
42 \cdot 7\end{array}$ & $\begin{array}{l}215.5 \\
310 \cdot 3 \\
264.3\end{array}$ & $\begin{array}{l}36 \cdot 1 \\
24 \cdot 0 \\
42 \cdot 4\end{array}$ & $\begin{array}{r}125 \cdot 8 \\
88 \cdot 0 \\
95 \cdot 8\end{array}$ & $\begin{array}{l}2 \cdot 0 \\
3 \cdot 8 \\
3 \cdot 2\end{array}$ & $\begin{array}{l}100 \\
365 \\
445\end{array}$ \\
\hline 6 & $\begin{array}{l}58 \cdot 3 \\
67 \cdot 2 \\
47 \cdot 6\end{array}$ & $\begin{array}{l}28 \cdot 1 \\
25 \cdot 4 \\
26 \cdot 3\end{array}$ & $\begin{array}{l}34 \cdot 7 \\
34 \cdot 8 \\
36 \cdot 8\end{array}$ & $\begin{array}{l}185 \cdot 5 \\
318 \cdot 4 \\
294 \cdot 1\end{array}$ & $\begin{array}{l}20 \cdot 9 \\
25 \cdot 4 \\
16 \cdot 5\end{array}$ & $\begin{array}{r}108.6 \\
86.0 \\
110.9\end{array}$ & $\begin{array}{l}1 \cdot 9 \\
4.0 \\
2 \cdot 8\end{array}$ & $\begin{array}{l}120 \\
235 \\
292\end{array}$ \\
\hline 7 & $\begin{array}{l}45 \cdot 4 \\
39 \cdot 2\end{array}$ & $\begin{array}{l}34 \cdot 1 \\
28 \cdot 6\end{array}$ & $\begin{array}{l}34 \cdot I \\
40 \cdot 6\end{array}$ & $\begin{array}{l}221 \cdot 1 \\
264 \cdot 0\end{array}$ & $\begin{array}{l}17 \cdot 2 \\
14 \cdot 9\end{array}$ & $\begin{array}{l}68 \cdot 1 \\
84 \cdot 5\end{array}$ & $\begin{array}{l}3 \cdot 5 \\
3 \cdot 3\end{array}$ & $\begin{array}{l}445 \\
500\end{array}$ \\
\hline 8 & $\begin{array}{l}41 \cdot 4 \\
36 \cdot 7\end{array}$ & $\begin{array}{l}32 \cdot 1 \\
28 \cdot 3\end{array}$ & $\begin{array}{l}17 \cdot 9 \\
33 \cdot 2\end{array}$ & $\begin{array}{l}195 \cdot 7 \\
272 \cdot 8\end{array}$ & $\begin{array}{l}17.5 \\
15.5\end{array}$ & $\begin{array}{l}71 \cdot 1 \\
60 \cdot 1\end{array}$ & $\begin{array}{l}3 \cdot 0 \\
4 \cdot 8\end{array}$ & $\begin{array}{l}535 \\
580\end{array}$ \\
\hline 28 & $\begin{array}{l}37 \cdot 6 \\
33 \cdot 8 \\
48 \cdot 4\end{array}$ & $\begin{array}{l}33.0 \\
29.0 \\
30.2\end{array}$ & $\begin{array}{l}27 \cdot 4 \\
39 \cdot 7 \\
40 \cdot 1\end{array}$ & $\begin{array}{l}247 \cdot 0 \\
223 \cdot 4 \\
207 \cdot 8\end{array}$ & $\begin{array}{l}18.5 \\
12.8 \\
17.9\end{array}$ & $\begin{array}{l}63 \cdot 2 \\
56 \cdot 2 \\
66 \cdot 4\end{array}$ & $\begin{array}{l}4 \cdot 2 \\
4 \cdot 2 \\
3 \cdot 4\end{array}$ & $\begin{array}{l}540 \\
530 \\
575\end{array}$ \\
\hline
\end{tabular}

- The total carotenoids include, besides $x$ - and $\beta$-carotene and lycopene, other carotenoids without vitamin $A$ potency, absorbing at $45 \mathrm{I} \mathrm{m} \mu$., of which the chief is xanthophyll (lutein).

red palm oil were used for comparison to confirm the identity of the milk pigments. Quantitative partition of carotene into $\alpha$ - and $\beta$-fractions is recorded in Table 8 . The concentration of both carotenes decreased in the milk as lactation progressed, the fall in the $\alpha$-fraction being the greater.

It is clear from Table 7 that the content of biologically active carotenoids in human milk was small relative to the concentration of preformed vitamin $A$, and that the infant must rely little if at all on them as a source of vitamin $A$ potency. The result is in agreement with that of Kon $\&$ Mawson (r950). Most of the vitamin A, as is seen from Table 7 , was in the form of the ester. 
Table 8. Content of $\alpha$ - and $\beta$-carotene and total carotene in eight individual samples of human milk, collected from 3 to 28 days after parturition

\begin{tabular}{|c|c|c|c|c|}
\hline \multirow[b]{2}{*}{$\begin{array}{c}\text { Days } \\
\text { post } \\
\text { partum }\end{array}$} & \multicolumn{3}{|c|}{ Carotene content } & \multirow[b]{2}{*}{$\begin{array}{c}\text { Ratio } \\
\beta \text {-carotene } \\
\alpha \text {-carotene }\end{array}$} \\
\hline & $\begin{array}{c}\text { Total } \\
(\mu \mathrm{g} . / \mathrm{ro0} \mathrm{ml} .)\end{array}$ & $\begin{array}{c}\beta \text {-carotene } \\
(\mu \mathrm{g} . / \text { roo ml. })\end{array}$ & $\begin{array}{c}\alpha \text {-carotene } \\
(\mu \mathrm{g} . / \text { I } 00 \mathrm{ml} .)\end{array}$ & \\
\hline 3 & $29^{\circ} 4$ & $17 \cdot 7$ & 10.4 & $1 \cdot 70$ \\
\hline 3 & 42.5 & 25.8 & 15.9 & $1 \cdot 62$ \\
\hline 3 & $31 \times x$ & $17 \cdot 8$ & 12.5 & $1 \cdot 42$ \\
\hline 4 & 25.6 & 19.9 & 10.9 & $x \cdot 83$ \\
\hline 5 & 19.5 & 13.2 & $6 \cdot 1$ & $2 \cdot 16$ \\
\hline 6 & 16.4 & $\mathrm{II}_{4}$ & 4.5 & 2.53 \\
\hline & $11 \cdot 2$ & 6.9 & 3.7 & 1.87 \\
\hline 28 & 9.7 & 6.5 & $2 \cdot 1$ & $3 \cdot 10$ \\
\hline
\end{tabular}

DISCUSSION

Protein. Our observations showed that human lactation differs from that of the cow in the behaviour of the protein content of the secretion. The samples of human colostrum studied had a smaller concentration of protein than those of the later milk, whereas cow's colostrum is richer in protein than the later milk. The concentration of protein increased as lactation proceeded, whereas in the cow the colostrum, initially rich in protein, gives way to milk of smaller protein content. The differences may perhaps be related to the richness of cow's colostrum in globulin with its accompanying content of antibodies. In the human being such antibodies are chiefly acquired in utero, and the neonatal requirement for globulin is consequently less. The calf grows more rapidly than the human infant, and therefore needs a liberal intake of calcium phosphate for bone growth, which in turn necessitates a larger content of casein in the milk in order to prevent the precipitation of calcium phosphate.

Nitrogen and phosphorus. According to Owen (1948), the ratio of nitrogen to phosphorus in cow's milk shows variations attributable to the activity of the thyroid gland, because thyroxine increases the phosphorus content of the milk without much affecting the concentration of nitrogen or of calcium. In cows the average percentage concentration of nitrogen is 0.6 and of phosphorus $0 . \mathrm{I}$, giving a ratio of $\mathrm{N}: \mathrm{P}$ of $6: \mathrm{I}$. The present figures give percentages for human milk of 0.300 and 0.015 , and a ratio of $N: P$ of $20: 1$.

Observations now being prepared for publication show that in the cow the $N: P$ ratio was reduced to about 5 by treatment with thyroxine or increased to about 7 by treatment with thiouracil. Administration of thyroxine increases total phosphorus in cow's milk by from 15 to $20 \%$ (Owen, 1948; Chanda \& Owen, 1949) and thiouracil decreases it from 10 to $15 \%$ (Chanda \& Owen, 1949).

Phosphatase. In the present experiments the amount of phosphatase in human colostrum and milk varied in a manner similar to that found in other species. Chanda \& Owen (1949) found a significant negative coefficient of correlation between the amounts of ester phosphorus and of phosphatase in cow's milk. The coefficient increased on treatment with thyroxine or thiouracil. Further studies of colostrum and late milk of cows showed that this correlation was true throughout lactation, in spite of the large variations in the amount of phosphatase demonstrated by Folley \& Kay (1936-7). By 
analogy, therefore, between the bovine and human species it would be expected that the much smaller phosphatase titre of human milk would be associated with a much greater proportion of ester phosphorus. This was indeed found to be so in the present investigations, for human milk had from $2 \mathrm{I}$ to $38 \%$ of the phosphorus as ester, whereas in cow's milk the percentage was only 10. Later observations, now being prepared for the press, show that in the concentrations of phosphatase and of ester phosphorus, the goat resembles the human being and not the cow. Basu $\&$ Mukherjee (1943), however, found that the amounts of ester phosphorus in goat's milk were smaller, and similar to those in cow's milk; their results are thus at variance with the present observations. They did not, however, appreciate the necessity for comparing milk at similar stages of lactation.

Some correlations of milk constituents are recorded in Table 3 , which shows that the amounts of lipid phosphorus and of phosphorylated vitamin $B_{1}$ also were negatively correlated with the amount of phosphatase, but there was a positive correlation between the amounts of inorganic phosphate and of phosphatase. These correlations are consistent with the hypothesis that ester phosphorus is the intermediary in metabolism between inorganic phosphate and lipid and casein phosphorus. The results of Chanda \& Owen (1949), already cited, also are consistent with that hypothesis. The intermediary ester phosphorus may be supposed to be synthesized in the mammary epithelium by phosphatase from inorganic phosphate. The correlation between the amount of phosphatase and the percentage of phosphorylated vitamin $B_{1}$ was -0.905 (Table 3 ). The closeness of the correlation is shown by Fig. 4 . As much as $90 \%$ of the vitamin $B_{1}$ was present in human milk in the phosphorylated form, a value which may be compared with $30 \%$ found by Neuweiler (1 94I) who, however, did not record the days post partum on which his samples were collected. The present experiments gave the percentage as from $5^{2}$ to 69 even on the 28 th day post partum. The inverse correlation between the amount of phosphatase and the ratio of phosphorylated to total vitamin $B_{1}$ has been previously noted in cow's and goat's milk by Houston et al. (1940), in cow's milk by Chanda et al. (1949) and in sow's milk by Braude, Coates, Henry, Kon, Rowland, - Thompson \& Walker (1947). Bartlett, Rowland \& Thompson (1949) observed a decreased ratio of free to total vitamin $B_{1}$ in the milk of cows ingesting thyroxine or iodinated protein; they did not record the amount of phosphatase but clearly stated the trend. A noteworthy feature of the experiments of Chanda \& Owen (1949) was the use of thiouracil to produce hypothyroid animals. In these animals the ratio of the amounts of phosphorylated to total vitamin $B_{1}$, the percentage of phosphoric esters, and the percentage of phospholipin declined as the amount of phosphatase increased, so that the large negative correlations between the amounts of phosphatase and of other milk constituents still persisted. The persistent interdependence of the amounts of phosphorylated compounds and phosphatase is probably related to the power of thyroxine to increase the concentration of enzymes in the body. Such an increase would necessitate an increase of the body's phosphorylated coenzymes which are so important in energy transfers.

Vitamin $B_{1}$. The total concentration of vitamin $B_{1}$ in the milk (Table 5 ) increased steadily as lactation progressed, becoming steady after the 8 th day, and an inspection 
of the milk yields in Table 7 shows that the output of vitamin $B_{1}$ also must have increased considerably as lactation progressed. The amounts of vitamin $B_{1}$ in the milk were larger than those reported by Kendall (r942), and from the United States by Roderuck, Williams \& Macy (1945). The observations of Kon \& Mawson (1950) suggest that large variations in the vitamin $B_{1}$ content of the milk are to be expected according to the degree of extraction of the bread flour in the mothers' diets and whether it is fortified with vitamin $B_{1}$ or not. That the intake of vitamin $B_{1}$ affects the amount in the milk is generally agreed (Slater \& Rial, 1942; Escudero \& de Esquef, 1944; Roderuck et al. 1945; Clements, 1949; Kon \& Mawson, 1950).

Carotenoids and vitamin $A$. The occurrence of lycopene in human milk (Thompson et al. 1942) and in cow's milk has previously been observed and it is known to be of dietary origin (Thompson, Ganguly, Mawson \& Kon, 1949). We do not know to what extent tomatoes or swede turnips contributed to the occurrence of lycopene in the present samples. The occurrence of $\beta$-carotene is attributable to consumption of any greenstuff, but its occurrence with $\alpha$-carotene is probably due to the eating of carrots. The great variation between samples in the content of vitamin $A$ is perhaps due to failure on the part of some of the mothers to take the vitamin capsules supplied by the welfare centres and hospitals.

\section{SUMMARY}

I. Samples of normal milk from mothers delivered in the Aberdeen Maternity Hospital were collected at intervals up to 28 days after parturition, and were analysed for certain constituents, with the following results.

2. The percentage of protein was very small, 0.63 , on the 2 nd day post partum, but rose to $2 \cdot 01$ the next day and remained at about that level thereafter.

3. The percentage of fat ranged from 2.5 to 3.9 and was much more variable than that of protein.

4. The percentage of solids-not-fat varied from 9 to ro with an initial figure of about $\mathrm{II} \cdot 2$.

5. The amounts of inorganic, ester and lipid phosphorus were closely correlated with the phosphatase content of the milk, that of inorganic phosphorus positively, and of ester and of lipid phosphorus negatively. The amount of phosphatase in the milk was large at first, falling as lactation progressed.

6. The $N: P$ ratio was 20 in human milk, compared with only 6 in cow's milk.

7. The amount of nicotinic acid increased from $42 \mu \mathrm{g} . / 100 \mathrm{ml}$. on the $3^{\text {rd day }}$ post partum to $226 \mu \mathrm{g} / 100 \mathrm{ml}$. on the 28 th day.

8. Phosphorylated vitamin $B_{1}$ behaved like ester phosphorus in its relationship to phosphatase, the negative correlation between the amounts of the two being close.

9. The amount of total vitamin $B_{1}$ increased steadily as lactation progressed. Comparison of the values obtained with those published by others served to strengthen the general belief that the amount of vitamin $B_{1}$ in the milk is readily affected by dietary intake.

10. On the basis of the present analyses an infant's total intake of vitamin A could vary very widely. 
II. The vitamin A activity of the milk was mainly due to vitamin A itself; the contribution from carotenes was very small. Of the vitamin A more than $90 \%$ was in the ester form.

12. Two-thirds to four-fifths of the activity of the carotenes was due to $\beta$-carotene and the remainder to $\alpha$-carotene.

13. Lycopene, which is not a precursor of vitamin A, formed one-quarter to onehalf of the total carotenoids. Inactive xanthophylls were present also, but no attempt was made to estimate them quantitatively.

14. The vitamin A concentration in the milk fat was larger at first than later in lactation.

15. The results for human milk are compared with those obtained recently for cow's milk.

The authors wish to thank Dr A. M. Thomson of the Midwifery Department of Aberdeen University for arranging for the samples to be made available to them, and also Miss P. McGuigan, Miss S. McLauchlan and Miss M. Millar of the Hannah Institute for their skilled technical help. They wish to thank also Prof. R. A. Morton of Liverpool for advice about spectrophotometry. It is a pleasure to record many interesting conversations with Dr Kon and his colleagues both at the Hannah Institute and at the National Institute for Research in Dairying at Reading. Finally, thanks are due to Dr J. G. Heathcote for supplying a culture of Lactobacillus arabinosus $17 / 5$, and to Messrs Lever Brothers and Unilever Ltd. for a sample of red palm oil.

One of us (R.C.) was a Government of India Scholar during the period of these experiments, and is now in receipt of a grant from the Agricultural Research Council.

\section{REFERENCES}

Bartlett, S., Rowland, S. J. \& Thompson, S. Y. (1949). Int. Dairy Cong7. XII, Stockholm, I, I02.

Barton-Wright, E. C. (1944). Biochem. F. 38, 314 .

Basu, K. P. \& Mukherjee, K. P. (1943). Indian f. vet. Sci. 13, 231.

Braude, R., Coates, M. E., Henry, K. M., Kon, S. K., Rowland, S. J., Thompson, S. Y. \& Walker, D. M. (1947). Brit. F. Nutrit. x, 64.

Chanda, R., McNaught, M. L. \& Owen, E. C. (1949). Biochem. F. 45, xix.

Chanda, R. \& Owen, E. C. (1949). Biochem. F. 44, xxix.

Clements, F. W. (1949). Infant Nutrition: its Physiological Basis. Bristol: John Wright.

Escudero, P. \& de Esquef, L. P. (1944). Rev. Asoc, argent. Dietol. 2, 107.

Fiske, C. H. \& Subbarow, Y. (1925). Y. biol. Chem. 66, 375.

Folley, S. J. \& Kay, H. D. (1936-7). Enxymologia, r, 48.

Ganguly, J., Kon, S. K. \& Thompson, S. Y. (1947). Brit. F. Nutrit. r, iii.

Graham, W. R. Jr. \& Kay, H. D. (1934). F. Dairy Res. 5, 54 .

Horecker, B. L., Ma, T. S. \& Haas, E. (1940). F. biol. Chem. 136, 775.

Houston, J., Kon, S. K. \& Thompson, S. Y. (1940). Ұ. Dairy Res. II, 145.

Kay, H. D. \& Graham, W. R. Jr. (1935). F. Dairy Res. 6, I91.

Kendall, N. (1942). F. Pediat. 20, 65.

Kinnersley, H. W. \& Peters, R. A. (1938). Biochem. Э. 32, 1516.

Kon, S. K. \& Mawson, E. H. (1950). Spec. Rep. Ser. med. Res. Coun., Lond., no. 269.

Morton, R. A. (1942). The Application of Absorption Spectra to the Study of Vitamins, Hormones and Coenzymes, and ed. London: Adam Hilger.

Morton, R. A. \& Stubbs, A. L. (1946). Analyst, 7r, 348.

Neave, F. K. (1939). F. Dairy Res. 10, 475.

Neuweiler, W. (x94I). Klin. Wschr. 20, 1072.

Olson, F. R., Hegsted, D. M. \& Peterson, W. H. (1939). J. Dairy Sci. 22, 63. 
Owen, E. C. (1948). Biochem. Ү. 43, 243.

Roderuck, C. E., Williams, H. H. \& Macy, I. G. (1945). Amer. F. Dis. Child. 70, 162.

Slater, E. C. \& Rial, E. J. (1942). Med. F. Aust. I, 3.

Thompson, S. Y., Ganguly, J., Mawson, E. H. \& Kon, S. K. (1949). Int. Dairy Congr. xII, Stockholm, 2, 238.

Thompson, S. Y., Kon, S. K. \& Mawson, E. H. (1942). Biochem. $\mathcal{~ f . ~ 3 6 , ~ x v i i . ~}$

World Health Organization: Expert Committee on Biological Standardization (1949). Report of the Subcommittee on Fat-Soluble Vitamins. WHO/BS/65 Rev. I. 